\title{
Field and Post-Harvest Factors Affecting the Quality and Shelf Life of Soft Fruits
}

\author{
Nika Cvelbar Weber* \\ Agricultural Institute of Slovenia, Slovenia
}

ISSN: 2637-7659

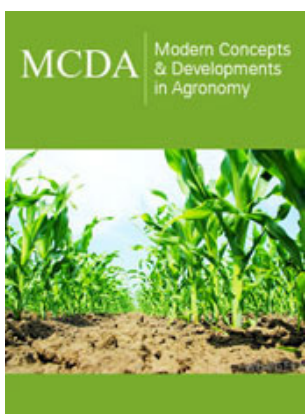

*Corresponding author: Nika Cvelbar Weber, Agricultural Institute of Slovenia, Hacquetova ulica 17, SI-1000 Ljubljana, Slovenia

Submission: 㘹April 27, 2020

Published: 眥 May 15, 2020

Volume 6 - Issue 2

How to cite this article: Nika Cvelbar Weber. Field and Post-Harvest Factors Affecting the Quality and Shelf Life of Soft Fruits. Mod Concep Dev Agrono. 6(2). MCDA. 000634. 2020. DOI: 10.31031/MCDA.2020.06.000634

Copyright@ Nika Cvelbar Weber, This article is distributed under the terms of the Creative Commons Attribution 4.0 International License, which permits unrestricted use and redistribution provided that the original author and source are credited.

\begin{abstract}
Soft fruit production is an economically important income for many producers all over the world. One of the main problems is the sensitivity of this small but very aromatic, health beneficial and desirable fruits. Despite the numerous benefits that soft fruits are valued for, post-harvest losses make its production in most parts of the world unprofitable and difficult to export. Soft fruits differ to most other fruits; they are so called non-climacteric fruit and are not able to ripen after they are harvested. Therefore, special pre-harvest and post-harvest treatments are necessary to reduce post-harvest losses in soft fruit, which, without special care can be as high as $40 \%$. This study revealed that the post-harvest quality status of soft fruits partly depended on some pre-harvest practices carried out during production. Some of these factors are nutrient management, maturity stage, cultivar selection and irrigation. Using best post-harvest handling practices or factors such as temperature, relative humidity, storage in controlled atmosphere and physical handling procedures to maintain the quality after harvest was also critical. It was concluded by this study that understanding and managing both pre-harvest and post-harvest factors properly would reduce the post-harvest quality losses in soft fruit production.
\end{abstract}

Keywords: Soft fruits; Shelf life; Pre-harvest and post-harvest; Quality; Storage

Abbreviation: MA: Modified Atmospheres; CA: Controlled Atmosphere

\section{Introduction}

Soft fruits are one the most popular and extensively consumed fruits in the world [1] Today's consumers are in demand of high quality, nutritionally versatile and safer fruits [2] throughout the year regardless of the season. Special interest in soft fruits is rising because they are a good source of natural antioxidants and beside the usual nutrients such as vitamins and minerals, soft fruits contain remarkably high content of phenolic compounds [3]. Soft fruits contain higher amounts of anthocyanins, a type of phenolic compounds that are beneficial in reducing the incidence of some chronic diseases [4]. Many researchers have shown a positive correlation between antioxidant activity and phenolic content especially anthocyanins [4]. Anthocyanins are responsible for the colour of the fruit [3] and among soft fruits; we can observe fruits in various different colours, from black and blue to yellow and red. World soft fruit production in 2018 accounts for about 750.000 hectares of harvested land area with an estimated production of 12 million tonnes [5]. Most economically important soft fruits in the world are strawberries and blueberries. Strawberries (Fragariaxananassa Duch.) are the main soft fruits as they are cultivated commercially in 76 countries [6] on approximately $50 \%$ of total soft fruit production area with the production of 8.4 million tonnes. China leads world strawberry production with about 3 million tonnes followed by United States of America with 1.3 million tonnes [5]. Second economically most important soft fruits are blueberries (Vaccinium spp.) which became one of the crops with the highest production trends. Worldwide production of blueberries has grown by $72.11 \%$ in last 20 years mostly in the United States of America, where $48 \%$ of the blueberries are harvested [5]. Soft fruit production is an important source of income for many producers all over the world [6]. Most of the soft fruit production is destined for the fresh market sector, which requires optimum pre-harvest production technology providing high-quality berries and post-harvest longevity [7]. Despite the numerous benefits that soft fruits are valued for, post-harvest losses make its production in most parts of the world unprofitable and difficult to export. Soft fruits 
differ to most other fruits; they are so called non-climacteric fruit and are not able to ripen once they are harvested [8].

Therefore, special pre-harvest and post-harvest treatments are necessary to reduce post-harvest losses in soft fruit, which, without special care can be as high as $40 \%$ globally [9]. These losses bring low economic efficiency to the producers as well as to the whole production country [6]. An investigation into the possible factors that can affect the post-harvest quality of soft fruits is therefore necessary to extend the post-harvest life of fresh soft fruits to further extend the marketing season and to reduce waste. The post-harvest qualities of soft fruits are dependent not only on post-harvest handling and treatment methods but also on many pre-harvest factors such as genetic and environmental conditions [10]. Production technology, such as fertilization [11], water supply [12], pest and disease management [13] and harvesting methods [14] are also believed to be factors influencing both pre- and postharvest quality of soft fruits. Many post-harvest quality losses are a result of different pre-harvest factors and fruits that are infected by pest, diseased, inappropriately irrigated and fertilized can never be improved in quality by any post-harvest treatment [15]. The aim of this review therefore is to investigate the most important pre-harvest and post-harvest factors and its effect on post-harvest qualities and shelf life of soft fruits, mainly strawberries and blueberries.

\section{Discussion}

\section{Pre-harvest factors affecting the post-harvest quality}

The following describes some of the most important field factors and production technologies affecting the shelf life and post-harvest qualities of soft fruits.

Nutrient management: When we say nutrient management, we first think about fertilization with nitrogen, being indispensable element for the development of the plant [16]. Producers all over the world often use high doses of $\mathrm{N}$ with the belief that it promotes vegetative development and higher fruit yield [17]. Deficiency of nitrogen in strawberry (content of nitrogen in leaves 1.9\%) causes chlorosis of the leaves and a significant decrease in leaf area, yield and root size [18]. However, an excess of nitrogen (content of nitrogen in leaves 4\%) promote vegetative growth, delays maturation, increase susceptibility to diseases and pathogen attack and causes a loss of firmness in the fruit $[19,20]$. Because of the general decrease in fruit quality, post-harvest handling could easily be affected. Higher concentration of nitrogen significantly reduces post-harvest life probably due to calcium deficiency in fruit [21]. Calcium deficiency represents one of the most common issues for strawberry growers. Calcium plays a role in cell division and the maintenance of cell permeability and cell integrity, all of which directly influence factors such as firmness and shelf life [22].

Therefore, many researchers have shown that calcium application had positive influence on different quality parameters. For instance, Ca application in blueberry production has recently been studied and found to be useful to delay post-harvest softening and decrease weight loss of blueberry fruits [11]. Foliar calcium application in strawberry production had a positive effect on the prevention of post-harvest rots [23] and increases fruit firmness [22]. Among microelements, boron has a direct effect on fruit quality. For example, boron deficiency causes partial flowers and deformed fruits, reduces yield, and increases defect [17]. Postharvest calcium application can also have a positive storage effect on strawberry fruits. Dipping the fruits in $1 \% \mathrm{CaCl} 2$ solution is an effective treatment for increasing the calcium content of the fruits, for controlling their post-harvest decay, and for maintaining their firmness and soluble solids content [24].

Maturity stage: The maturity stage of soft fruits at harvest is probably one of the most critical elements of many quality traits and shelf life. Soft fruits, being a non-climacteric fruit, cannot be harvested before they are fully red and reach at $7-8 \%{ }^{\circ}$ Brix value to guaranty the fruit quality (Figure 1). Thus, this may extend its shelf life on the cost of flavour and nutritional value. Harvesting strawberries at the fully ripe stage is preferred to maximise nutritional value but limiting shelf life, because of fruit softening and increased susceptibility to physical injuries [25]. Unripe fruits are more prone to shrivelling and physical injuries, and have poor flavour quality when ripe [26]. Fruits either picked too early or too late in their season are more susceptible to post-harvest physiological disorders than fruits picked at the proper stage of maturity [27]. Decay incidence was found higher at fully ripe fruits than three-quarter ripe fruits [28].

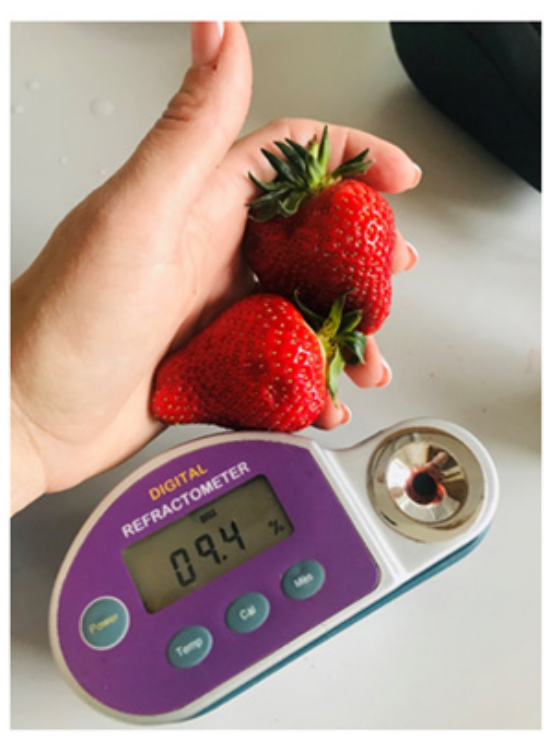

Figure 1: Properly mature strawberry fruits for harvest.

Cultivar: The potential quality of fruit is very dependent on the cultivar. Different cultivars are characterised by different quality parameters making some more desirable to the producers and consumers than others. Post-harvest life based on appearance and on changes in flavour components and sensory characteristics of different strawberry cultivars during storage showed significant differences in fruit firmness and flavour quality during storage [29]. Cultivar selection is therefore an important factor to consider also depending on the market distance.

Irrigation: A deficiency or excess of water can affect the quality of crops if they are consume immediately or stored [30]. 
Management of water frequently poses a dilemma between yield, fruit quality and shelf life. Extreme water stress will reduce yield and quality of the fruit, but may benefit some taste related compounds [30,31]. If strawberry plants are over-irrigated, especially at harvest time, the fruits have a sour taste; they are softer and more susceptible to bruising and decay [32]. According to [12] the effect of irrigation intervals on the quality and storage performance of strawberry fruit is also important. They concluded that while 4 days irrigation interval may be optimum for fresh fruit consumption, irrigation interval of 10 days is appropriate for retaining quality during storage or distant marketing.

\section{Post-harvest factors affecting the post-harvest quality}

Post-harvest handling and storage techniques have one main goal, to maintain the maximum quality of fruits from harvesting to consumer. With prolong shelf life and retained consumer appeal, the grower will receive the highest market price at the time for sale. This chapter is devoted to provide information on quality retention in fresh soft fruits through proper post-harvest handling and storage.

Temperature: Low temperature is the most common method used to extend storage life [29]. All soft fruits must be chilled immediately after harvesting, so called precooling, in order to maximize the shelf life [33]. For example, strawberries rapidly cooled down to $0^{\circ} \mathrm{C}$ showed threefold the storage life of those fruit maintained at $10{ }^{\circ} \mathrm{C}[34]$. Temperatures around $0{ }^{\circ} \mathrm{C}$ are considered the best for strawberry [35], $2-5{ }^{\circ} \mathrm{C}$ for blueberry and raspberry $[36,37]$ storage because they cause few changes in quality. However, the commercialization and post-market storage usually occur at higher temperatures. These higher temperatures can affect not only the strawberry shelf life, but also its nutritional value, in terms of soluble sugars, vitamin $\mathrm{C}$ and antioxidant compounds [35]. Temperature management during storage is the single most important factor in minimizing the deterioration of fruit quality and extending the shelf life of strawberry. Not only that we lower the temperature of the atmosphere around the fruits, it is also important how. The aim of the research carried out by Allais [38] was to assess the impact of mist-chilling on high-grade strawberry. Mist-chilling had reduced weight loss by $20-40 \%$ in comparison to air-chilling. Beside air and mist chilling, it is also used hydro cooling to lower the temperature of the fruits. Emond [39] studied the feasibility of hydro cooling for strawberries and it resulted not suitable for strawberry.

Relative humidity: High humidity is essential for stored soft fruits; moisture promotes the growth of disease-causing organisms. This can be offset by maintaining adequate air circulation and applying the coldest storage temperature allowable for each fruit without causing any injuries. Berries are mostly water and soluble solids such as sugars and acids that depress the freezing point below $0{ }^{\circ} \mathrm{C}$. Optimum humidity for soft fruit is between $85-95 \%$ [40].

Combination gases: The primary purpose of modified atmospheres (MA) and controlled atmosphere (CA) storage is to lower the respiration rate to slow biochemical changes in fruits and slow the ripening process. With this modification of storage conditions, beside the basic temperature and humidity demand, shelf life of soft fruits can be significantly extended [40]. CA and MA technologies can reduce the need for post-harvest pesticides and allow fully ripe fruit to be harvest. Controlled atmosphere demand for non-climacteric soft fruits is different than most of other climacteric fruits. The main difference is in low 02 and high CO2 levels that cause the disruption of the enzyme system in the ethylene production pathway. Strawberries, blackberries and raspberries have especially high rates of respiration, so the optimal CA is consist of $5-10 \% 02$ and $10-20 \%$ of $\mathrm{CO} 2$ [41].

Physical handling: Physical handling can have a drastic effect on the post-harvest quality or life of harvested fruits. As the term itself suggests, soft fruits are delicate and do not tolerate rough handling at any stage, resulting in mechanical injuries which decrease the quality and shelf life.

\section{Conclusion}

Post-harvest quality management of soft fruits starts in the orchard and continues until it reaches the final consumer. Many post-harvest quality losses are a result of different pre-harvest factors and fruits that are infected by pest, diseased, inappropriately irrigated and fertilized can never be improved in quality by any post-harvest treatment Understanding and managing the various roles that pre-harvest factors like nutrition management, harvest, cultivar selection, and irrigation can play the main role. Soft fruits are highly delicate and are subjected to rapid quality loss after harvest. Using best post-harvest handling practices or factors such as optimum temperature, right relative humidity, optimal gases concentrations in storage and the best physical handling procedures to maintain the quality after harvest is also critical. It can be concluded by this study that pre-harvest and post-harvest factors must be managed properly in order to reduce the quality loss to minimum.

\section{Acknowledgement}

The authors acknowledge the financial support of the Slovenian Research Agency (grant No. P4-0133), as well as the Ministry of Education, Science and Sport of Republic of Slovenia and the ERDF under agreement No. C3330-17-529016 (reference "Raziskovalci2.0-KIS-529016).

\section{Conflict of Interest}

The authors declare that there is no conflict of interests regarding the publication of this paper.

\section{References}

1. OjedaReal L, Lobit P, Navarro RC, Cabrera OG, Rodríguez RF, et al. (2008) Effect of nitrogen fertilization on quality markers of strawberry (Fragaria×ananassa Duch. Cv. Aromas). J Sci Food Agric 89(6): 935-939.

2. Bhat R, Gappert KJ, Funken E, Stamminger R (2015) Consumers perceptions and preference for strawberries-A case study from Germany. Int J Fruit Sci 15(4): 405-424.

3. Weber N, Veberic R, Rescic J, MikulicPetkovsek M, Stampar F, et al. (2016) Alternative products against anthracnose affect selected primary and secondary metabolites in strawberry fruit. Fruits 71(6): 363-371. 
4. Wang SY, Lin HS (2000) Antioxidant activity in fruits and leaves of blackberry, raspberry, and strawberry varies with cultivar and developmental stage. J Agric Food Chem 48(2): 140-146.

5. Shahbandeh M (2020) Global fruit production in 2018, by selected variety. Statista.

6. Simpson D (2018) The economic importance of strawberry crops. In Hytönen T, Graham J, Harrison R (Eds.), The genomes of rosaceous berries and their wild relatives. Compendium of Plant Genomes, Springer, Germany, pp. 1-7.

7. Gallardo RK (2018) Blueberry producers attitudes toward harvest mechanization for fresh market. Horttech 28(1): 10-16.

8. Van de Poel B, Vandendriessche T, Hertog MLATM, Nicolai BM, Geeraerd A (2014) Detached ripening of non-climacteric strawberry impairs aroma profile and fruit quality. Post-harvest Boil Tec 95: 70-80.

9. Wright WR, Billeter BA (1975) Marketing losses of selected fruits and vegetables at wholesale, retail, and consumer levels in the Chicago area. USDA Mktg Res (1017).

10. Deák S, FüstösZ (2009) Shelf life and storage of strawberry varieties. Ptep 13(3): 229-231.

11. Angeletti P (2010) Effect of pre-harvest calcium applications on postharvest quality, softening and cell wall degradation of two blueberry (Vaccinium corymbosum) varieties. Post-harvest Biol Tech 58(2): 98103.

12. Akhtar I, Rab A (2015) Effect of irrigation intervals on the quality and storage performance of strawberry fruit. J Anim Plant Sci 25(3): 669678.

13. Cai Z, Yang R, Xiao H, Qin X, SiL (2015) Effect of pre-harvest application of Hanseniaspora uvarum on post-harvest diseases in strawberries. Post-harvest Boil Tec 100: 52-58.

14. NunezBarrios A, Nesmith DS, Chinnan M, Prussia SE (2008) Dynamics of rabbiteye blueberry fruit quality in response to harvest method and post-harvest handling temperature. Small Fruits Rev 4(2): 73-81.

15. Harvey JM (1987) Reduction of losses in fresh market fruits and vegetables. Annu Rev Phytopathol 16: 321-341.

16. Lawlor DW (2002) Carbon and nitrogen assimilation in relation to yield: Mechanisms are the key to understanding production systems. J Exp Bot 370: 773-787.

17. Netsby R, Lieten F, Pivot D, Raynal Lacroix C, Tagliavini M (2005) Influence of mineral nutrients on strawberry fruit quality and their accumulation in plant organs. Int J Fruit Sci 5(1): 139-156.

18. Yoshida Y, Goto T, Hirai M, Masuda M (2002) Anthocyanin accumulation in strawberry fruits as affected by nitrogen nutrition. Acta Hort 567(77): 357-360.

19. Pritts M (2015) Nutrient management practices in perennial strawberry are informed by understanding the relationships among carbohydrate status, nitrogen availability, and soil composition. Hort Tech 25(4): 447451.

20. Neuweiler R (1997) Nitrogen fertilization in integrated outdoor strawberry production. Acta Hort 439: 747-752.

21. Tabatabaei SJ, Yusefi M, Hajiloo J (2008) Effects of shading and $\mathrm{NO}_{3}: \mathrm{NH}_{4}$ ratio on the yield, quality and $\mathrm{N}$ metabolism in strawberry. Sci Hortic 116(3): 264-272.

22. Singh R, Sharma RR, Tyagi SK (2007) Pre-harvest foliar application of calcium and boron influences physiological disorders, fruit yield and quality of strawberry (Fragaria×ananassa Duch.). Sci Hortic 112(2): 215-220.
23. Wójcik P, Lewandowski M (2011) Effect of calcium and boron sprays on yield and quality of "Elsanta" strawberry. J Plant Nutr 26(3): 671-682.

24. García JM, Herrera S, Morilla A (1996) Effects of post-harvest dips in calcium chloride on strawberry. J Agric Food Chem 44(1): 30-33.

25. Kader AA (1991) Chapter 29/Quality and its maintenance in relation to the post-harvest physiology of strawberry. In: Dale A, Luby JJ (Eds.), The Strawberry into the $21^{\text {st }}$, Timber Press, Portland, Oregon, USA, pp. 262284.

26. Rahman MM, Moniruzzaman M, Ahmad MR, Sarker BC, Alam MK (2016) Maturity stages affect the post-harvest quality and shelf-life of fruits of strawberry genotypes growing in subtropical region. J Saudi Soc Agric Sci 15(1): 28-37.

27. Kader AA (2013) Post-harvest technology of horticultural crops-An overview from farm to fork. Ethiop J Appl Sci Technol 1: 1-8.

28. Nunes MCN, Morais AMMB, Brecht JK, Sardent S (2002) Fruit maturity and storage temperature influence response of strawberries to controlled atmospheres. J Am Soc Hortic Sci 127(5): 836-842.

29. Pelayo C, Ebeler SE, Kader AA (2003) Post-harvest life and flavour quality of three strawberry cultivars kept at $5^{\circ} \mathrm{C}$ in air or air $+20 \mathrm{kPa} \mathrm{CO}$. Post-harvest Boil Tec 27(2): 171-183.

30. Weber N, Zupanc V, Jakopic J, Veberic R, Mikulic-Petkovsek M, et al. (2016) Influence of deficit irrigation on strawberry (Fragaria $\times$ ananassa Duch.) fruit quality. J Sci Food Agric 97(3): 849-857.

31. Bordonaba JG, Terry LA (2010) Manipulating the taste-related composition of strawberry fruits (Fragaria x ananassa) from different cultivars using deficit irrigation. Food Chem 122: 1020-1026.

32. Morris JR, Main GL, Sistrunk WA (1991) Relationship of treatment of fresh strawberries to the quality of frozen fruit and preserves. J Food Qual 14(6): 467-479.

33. Yang FM, Li HM, Li F, Xin ZH, Zhao LY, et al. (2010) Effect of nano-packing on preservation quality of fresh strawberry (Fragaria ananassa Duch. cv Fengxiang) during storage at $4{ }^{\circ} \mathrm{C}$. J Food Scie 75(3): C236-C240.

34. http://www.omafra.gov.on.ca/english/crops/facts/storage_berries.htm

35. Cordenunsi BR, Genovese MI, Olivera de Nascimento JR, Hassimotto NMA, dos Santos RJ, et al. (2005) Effect of temperature on the chemical composition and antioxidanr activity of three strawberry cultivars. Food Chem 91(1): 113-121.

36. Duan J, Wu R, Strik B, Zhao Y (2011) Effect of edible coatings of fresh blueberries (Duke and Elliott) under commercial storage conditions. Post-harvest Biol Tech 59(1): 71-79.

37. Krüger E, Dietrich H, Schöpplein E, Rasim S, Kürbel P (2011) Cultivar, storage conditions and ripening effects on physical and chemical qualities of red raspberry fruit. Post-harvest Biol Tech 60(1): 31-37.

38. Allais I, Letang G (2009) Influence of mist-chilling on post-harvest quality of fresh strawberries Cv Mara des Bois and Gariguette. Int J Refrig 32(6): 1495-1504.

39. Emond JP, Mercier F, Sadfra SO, Bouree M, Gakwaya A (1996)Study of parameters affecting cooling rate and temperature distribution in forced-air precooling of strawberry. ASABE 39(6): 2185-2191.

40. Forney CF, Jamieson AR, Pennell KDM, Jordan MA, Fillmore SAE (2015) Relationships between fruit composition and storage life in air or controlled atmosphere of red raspberry. Post-harvest Biol Tech 110: 121-130.

41. Haffner K, Rosenfeld HJ, Skrede G, Wang L (2002) Quality of red raspberry Rubus idaeus $L$. cultivars after storage in controlled and normal atmospheres. Post-harvest Biol Tech 24(3): 279-289. 